\title{
Analisis Faktor Risiko Hipertensi Pada Masyarakat Di Wilayah Pesisir Kota Pekalongan
}

\author{
Jaya Maulana ${ }^{1)}$, Wahid Fajar Nugraha ${ }^{2)}$
}

\author{
${ }^{1)}$ Dosen Prodi Kesehatan Masyarakat FIK UNIKAL, ${ }^{2)}$ Alumni Prodi Kesehatan Masyarakat FIK \\ UNIKAL, 1) jayamaulana76@gmail.com
}

\section{ARTICLE INFO :}

$\begin{array}{ll}\text { Accepted } & \text { : } \\ \text { Approve } & \text { : } \\ \text { Publish } & \text { : }\end{array}$

\section{ABSTRAK}

Latar Belakang. Hipertensi merupakan salah satu variabel yang sering menyebabkan gangguan kardiovaskular. Di Indonesia, hipertensi adalah masalah serius, selain karena prevalensi yang tinggi, penyakit ini juga berakibat fatal seperti penyakit jantung, stroke, gagal ginjal dan lainlain.

Tujuan Penelitian. Penelitian ini bertujuan unutuk mendapatkan informasi tentang faktor risiko hipertensi pada masyarakat pesisir Pekalongan.

Metode. Penelitian ini merupakan jenis penelitian analitik observasional dengan studi kasus kontrol. Jumlah responden adalah 72 sampel, terdiri dari 36 kasus dan 36 kontrol. Sampel yang dikumpulkan menggunakan metode consecutive sampling. Data dianalisis dengan bivariat dan multivariat dengan metode regresi logistik, menggunakan program SPSS.

Hasil. Hasil percobaan menunjukkan bahwa ada 2 faktor risiko yang berhubungan dengan kejadian hipertensi yaitu aktivitas fisik ( $\mathrm{p}=0,000$; $\mathrm{OR}=13,47 ; 95 \% \mathrm{CI}=3,52-51,58)$, dan pola istirahat ( $\mathrm{p}=0,016 ; \mathrm{OR}=0,196 ; 95 \% \mathrm{CI}=0,05-0,74)$.

Saran. Olahraga teratur dan terukur serta mengatur pola tidur yang disesuaikan dengan umur. Kata kunci: Faktor Risiko, Hipertensi

\section{ABSTRACT}

Background. Hypertension was one of the deases which often caused cardiovascular disorder and the reason from enhance of death number because of cardiovascular disorder that come from hypertension, was to know the hypertension risk factor and do the prevention. In Indonesia, hypertension was serious problem, beside because of the high prevalension, also the disease came from that is fatal like heart disease, stroke, kidney failure and others. Object. Arm of this experiment to get information about the amount of risk factor which adhere or cannot be change and the risk factor which can be change as hypertension risk factor.

Method. The experiment was kind of observasional analytic experiment with case control study. Number of respondent is 72 sample, consist of 36 cases and 36 control. Sample collected was using consecutive sampling method. The data was analyzing bivariat and multivariat with regression logistic method, using SPSS program.

Result. Experiment result shows that there were 2 risk factor which related to hypertension event that was physical activity ( $p=0,000 ; O R=13,47 ; 95 \% C I=3,52$ 51,58), and rest pattern ( $p=0,016 ; O R=0,196 ; 95 \% C I=0,05-0,74)$.

Suggestion. Regular and measurable exercise and adjust sleep patterns that are adjusted to age.

Keywords : Risk Factor, Hypertension. 


\section{LATAR BELAKANG}

Hiperetensi merupakan salah satu penyakit degeneratif yang masih menjadi masalah kesehatan di Indonesia. Hipertensi dikenal juga sebagai tekanan darah tinggi, dengan sistol diatas $140 \mathrm{mmHg}$ dan diastol diatas $90 \mathrm{mmHg}$ (Sherwood dkk, 2014). Gejala yang timbul biasanya tidak terlalu bermakna (Gray, 2007). Umunya berupa sakit kepala, epistaktis, jantung berdebar, sulit bernafas setelah bekerja keras atau mengangkat beban berat, mudah lelah, gampang marah, telinga berdengung, pusing, tinitus yang hampir sama dengan kebanyakan orang denga tensi normal. Gejala-gejala tersebut biasanya hanya terjadi pada hipertensi berat atau progresif(Rubbenstein,2007).

Hipertensi sering menimbulkan penyakit kardiovaskular, ginjal dan stroke (Yogiantoro,2006). Telah terdapat 9,4 juta orang dari 1 milyar orang di dunia yang mati akibat gangguan kardiovaskular. Data World Health Organization (WHO) tahun 2015 menunjukkan sekitar 1,13 Miliar orang di dunia terkena hipertensi, artinya 1 dari 3 orang di dunia terdiagnosis hipertensi. Jumlah penderita hipertensi terus meningkat setiap tahunnya, diperkirakan pada tahun 2025 akan ada 1,5 Miliar orang yang terkena hipertensi, dan diperkirakan setiap tahunnya 10,44 juta orang meninggal akibat hipertensi dan komplikasinya.

Terdapat berbagai faktor risiko yang dapat mempengaruhi terjadinya hipertensi. Pada penelitian Mannan $\mathrm{H}$ pada tahun 2012 hasil penelitian menunjukkan bahwa riwayat keluarga, perilaku merokok, aktifitas fisik dan konsumsi garam merupakan faktor risiko yang bermakna terhadap kejadian hipertensi. Sedangkan konsumsi kopi dalam penelitian tersebut merupakan faktor risiko yang tidak bermakna terhadap kejadian hipertensi (Mannan,2012). Selain itu, tingkat pengetahuan dan sikap juga dapat mempengaruhi kejadian hipertensi. Penelitian Musthofa tahun 2013 di Puskesmas Ponorogo Utara Kabupaten Ponorogo menyatakan dari 50 responden ditemukan 21 responden (42\%) memiliki pengetahuan buruk (Mustofa, 2013). Riset kesehatan dasar (Riskesdas) yang dilakukan oleh kemenkes pada tahun 2018 menunjukkan adanya peningkatan prevalensi hipertensi pada penduduk perkotaan dengan angka yang mencapai $34,1 \%$.Salah satu daerah yang terletak di perkotaan adalah di daerah pesisir pantai Boom Kecamatan Pekalongan Utara Kota Pekalongan. ${ }^{7}$ Profil kesehatan kota 
pekalongan tahun 2014-2016 menyebutkan bahwa angka kejadian hipertensi cenderung mengalami kenaikan. Data dari Puskesmas Kusumabangsa memeperlihatkan bahwa hipertensi menduduki peringkat ke dua dari 10 penyakit terbesar. Masih dari data Puskesmas Kusumabangsa menyebutkan bahwa sejak Agustus sampai September 2018 tercatat terdapat 114 kasus hipertensi dan mengalami kenaikan dari bulan-bulan sebelumnya. Dari data yang dipaparkan, kejadian hipertensi ini lebih banyak terjadi pada masyarakat yang tinggal diwilayah pesisir kota Pekalongan.

Berdasarkan latar belakang tersebut peneliti bermaksud untuk melakukan penelitian tentang faktor resiko kejadian hipertensi pada masyarakat di Pesisir Pantai Boom Kecamatan Pekalongan Utara Kota Pekalongan.

\section{METODE}

Desain penelitian ini merupakan metode penelitian analitik deskriptif yaitu menggunakan desain case control study untuk melihat faktor risiko hipertensi pada masyarakat di Pesisir Pantai Boom

Kecamatan Pekalongan Utara Kota
Pekalongan.

\section{Tempat Dan Waktu Penelitian}

Penelitian ini dilaksanakan di wilayah kerja Puskesmas Kusumabangsa pada bulan September - Oktober 2018. Poulasi dari penelitian ini adalah masyarakat di Pesisir Pantai Boom Kecamatan Pekalongan Utara Kota Pekalongan. Populasi kelompok kasus pada penelitian ini adalah masyarakat yang menderita penyakit hipertensi di wilayah kerja Puskesmas Kusumabangsa dan populasi kontrol pada penelitian ini adalah masyarakat yang tidak menderita penyakit hipertensi di wilayah kerja Puskesmas Kusumabangsa. Teknik sampling yang digunakan adalah consecutive sampling, dengan jumlah sampel minimal sebesar 36 orang pada kasus dan 36 pada kontrol. Jadi jumlah keseluruhan sampel adalah 72 . Selanjutnya jumlah sampel ditambah $25 \%$ yaitu sebesar 18 orang sehingga total sampel keseluruhan pada penelitian ini berjumlah 90 orang. Alat yang digunakan dalam penggumpulan data penelitian ini adalah kuesioner yaitu daftar pertanyaan yang telah disusun dengan baik, matang, dimana responden tinggal memberikan jawaban. Data dianalisis secara bivariat dan multivariat untuk melihat hubungan faktor risiko dengan kejadian hipertensi pada masyarakat di Pesisir Pantai Boom Kecamatan Pekalongan Utara Kota Pekalongan. Data ini dianalisis secara bivariat dan multivariat untuk melihat 
hubungan faktor risiko dengan kejadian hipertensi pada masyarakat di pesisir Pantai Boom Kecamatan Pekalongan Utara Kota Pekalongan.

\section{HASIL}

\section{Karakteristik responden penelitian}

Penelitian ini telah dilakukan pada masyarakat di Pesisir Pantai Boom Kecamatan Pekalongan Utara Kota Pekalongan. Responden kasus pada penelitian ini sebanyak 36 orang dan responden kontrol pada penelitian ini sebanyak 36 orang

Tabel 1. Gambaran Karakteristik Responden di Pesisir Pantai Boom Kecamatan Pekalongan Utara Kota Pekalongan

\begin{tabular}{|c|c|c|c|c|c|c|}
\hline \multirow[t]{3}{*}{ KARAKTERISTIK RESPONDEN } & \multicolumn{4}{|c|}{$\begin{array}{l}\text { KEJADIAN } \\
\text { HIPERTENSI }\end{array}$} & \multirow[t]{4}{*}{$\mathrm{n}$} & \multirow[t]{3}{*}{$\%$} \\
\hline & \multicolumn{2}{|c|}{ KASUS } & \multicolumn{2}{|c|}{ KONTROL } & & \\
\hline & $\mathrm{N}$ & $\%$ & $\mathrm{~N}$ & $\%$ & & \\
\hline \multicolumn{6}{|l|}{ Umur } & \\
\hline 1. $<20$ tahun & 0 & 00,0 & 2 & 5,60 & 2 & 2,70 \\
\hline 2. 20-35 tahun & 3 & 8,40 & 5 & 13,9 & 8 & 11,2 \\
\hline 3. > 35 tahun & 33 & 91,6 & 29 & 80,5 & 62 & 86,1 \\
\hline \multicolumn{7}{|l|}{ Jenis Kelamin } \\
\hline 1. Laki-laki & 23 & 63,9 & 25 & 69,4 & 48 & 66,6 \\
\hline 2. Perempuan & 13 & 36,1 & 11 & 30,6 & 24 & 33,4 \\
\hline \multicolumn{7}{|l|}{ Pendidikan } \\
\hline 1. Tidak Tamat SD & 9 & 25,0 & 2 & 5,60 & 11 & 15,2 \\
\hline 2. SD & 16 & 44,4 & 12 & 33,4 & 28 & 38,8 \\
\hline 3. SMP & 6 & 16,6 & 10 & 27,7 & 26 & 36,1 \\
\hline 4. SMA & 2 & 5,60 & 10 & 27,7 & 12 & 16,6 \\
\hline 5. Perguruan Tinggi & 3 & 8,40 & 2 & 5.60 & 5 & 6,90 \\
\hline \multicolumn{7}{|l|}{ Pekerjaan } \\
\hline 1. PNS/Pensiunan PNS & 0 & 0,00 & 0 & 0,00 & 0 & 0,00 \\
\hline 2. POLRI/TNI/Pensiunan & 0 & 0,00 & 0 & 0,00 & 0 & 0,00 \\
\hline 3. Pegawai swasta/Wirasuasta & 3 & 8,40 & 1 & 0,00 & 4 & 5,50 \\
\hline 4. Pedagang & 12 & 33,4 & 12 & 33,4 & 24 & 33,4 \\
\hline 5. Petani & 0 & 0,00 & 0 & 0,00 & 0 & 0,00 \\
\hline 6. Buruh & 17 & 47,2 & 16 & 44,4 & 33 & 45,8 \\
\hline 7. Lainnya & 4 & 11,0 & 8 & 22,2 & 12 & 16,6 \\
\hline
\end{tabular}

Berdasarkan Tabel.1 dapat dilihat bahwa kontrol terbanyak yaitu sebesar $25(69,4 \%)$ sebagian besar responden berumur $>35$ responden dan tingkat pendidikan tahun sebanyak $33(916 \%)$ responden pada terbanyak yaitu SD sebesar $16(44,4 \%)$ kelompok kasus dan $29(80,5 \%)$ responden responden pada kelompok kasus dan 12 pada kelompok kontrol. Jenis kelamin $(33,4 \%)$ responden pada kelompok terbanyak pada kelompok kasus yaitu lakikontrol. laki sebanyak $23(63,9 \%)$ responden sedangkan jenis kelamin pada kelompok

\section{Analisis Bivariat}


Tabel 2. Hubungan variabel independen dengan kejadian hipertensi

Di Pesisir Pantai Boom Kecamatan Pekalongan Utara Kota Pekalongan.

\begin{tabular}{|c|c|c|c|c|c|c|c|c|}
\hline \multirow{3}{*}{$\begin{array}{l}\text { VARIABEL } \\
\text { INDEPENDEN }\end{array}$} & \multicolumn{4}{|c|}{ KEJADIAN HIPERTENSI } & $\mathrm{N}$ & $\%$ & $\mathrm{P}$ & OR \\
\hline & \multicolumn{2}{|c|}{ KASUS } & \multicolumn{2}{|c|}{ KONTROL } & & & Value & \\
\hline & $\mathrm{N}$ & & $\mathrm{N}$ & $\%$ & & & & \\
\hline \multicolumn{9}{|l|}{ Aktifitas Fisik } \\
\hline 1. Aktif & 20 & 55,5 & 15 & 41,6 & 35 & 48,6 & 0,000 & 0,102 \\
\hline 2. Pasif & 16 & 44,5 & 21 & 58,4 & 37 & 51,4 & & \\
\hline \multicolumn{9}{|l|}{ Pola Makan } \\
\hline 1. Baik & 25 & 69,4 & 10 & 27,7 & 35 & 48,6 & 0,821 & 1,229 \\
\hline 2. Tidak Baik & 11 & 30,6 & 26 & 72,3 & 37 & 51,4 & & \\
\hline \multicolumn{9}{|l|}{ Kebiasaan Istirahat } \\
\hline 1. Cukup & 10 & 27,7 & 23 & 63,8 & 33 & 45,8 & 0,159 & 2,182 \\
\hline 2. Kurang & 26 & 72,3 & 13 & 36,2 & 39 & 54,2 & & \\
\hline \multicolumn{9}{|l|}{ Kebiasaan Merokok } \\
\hline 1. Merokok & 20 & 55,5 & 9 & 25,0 & 29 & 40,2 & 0,230 & 2,017 \\
\hline 2. Tidak Merokok & 16 & 44,5 & 27 & 75,0 & 43 & 59,8 & & \\
\hline
\end{tabular}

Berdasarkan Tabel 4. dilihat bahwa hubungan yang paling bermakna antara variabel independen dengan kejadian hipertensi adalah aktifitas fisik dengan $\mathrm{p}$ value 0,000. Dari hasil uji statistik tersebut terdapat hubungan yang bermakna antara variabel independen tersebut dengan kejadian hipertensi, karna p value variabel $<0,005$.

Tabel 3. Hasil seleksi bivariat variabel-variabel independen dengan kejadian hipertensi di Pesisir Pantai Boom Kecamatan Pekalongan Utara Kota Pekalongan

\begin{tabular}{llcl}
\hline No & Variabel Independen & P Value & Keterangan \\
1. & Aktifitas Fisik & 0,000 & Kandidat \\
2. & Pola Makan & 0,821 & Bukan Kandiat \\
3. & Kebiasaan Istirahat & 0,159 & Kandidat \\
4. & Kebiasaan Merokok & 0,230 & Kandidat \\
\hline
\end{tabular}

Dari table 4. dapat dilihat bahwa variabel independen yang termasuk variabel kandidat adalah aktifitas fisik p 0,000,

\section{Analisis Multivariat}

Analisis mulitivariat digunakan untuk mengetahui faktor atau variabel yang paling berhubungan atau utuk mengetahui apakah ada variabel lain yang mempengaruhi hubungan tersebut. Analisis multivariate terdiri atas dua tahap yaitu seleksi bivariat dan pemodelan multivariat. 
Tabel 4. Analisis multivariat metode backward

\begin{tabular}{llll}
\hline Variabel Independen & P Value & OR & $(95 \% \mathrm{CI})$ \\
Step 1 & & & \\
$\quad$ Aktifitas Fisik & 0,000 & 15,792 & $(3,128-58,888)$ \\
$\quad$ Pola Makan & 0,164 & 1,937 & $(0,117-1,475)$ \\
$\quad$ Kebiasaan Istirahat & 0,008 & 7,085 & $(0,046-0,707)$ \\
$\quad$ Kebiasaan Merokok & 0,912 & 0,012 & $(0,274-4,258)$ \\
Step 2 & & & \\
$\quad$ Aktifitas Fisik & 0,000 & 13,186 & $(3,351-51,884)$ \\
$\quad$ Pola Makan & 0,176 & 0,419 & $(0,119-1,476)$ \\
$\quad$ Kebiasaan Istirahat & 0,014 & 0,014 & $(0,047-0,708)$ \\
Step 3 & & & $(3,522-51,585)$ \\
$\quad$ Aktifitas Fisik & 0,000 & 13,479 & $(0,052-0,742)$ \\
$\quad$ Kebiasaan Istirahat & 0,016 & 0,196 & \\
\hline
\end{tabular}

Pada tabel 4. telah dilakukan analisis multivariat dengan metode backward. Pada metode ini terdapat tiga langkah untuk mendapatkan hasil akhir. Pada langkah pertama, dimasukkan semua variabel. Pada langkah ini didapatkan hasil variabel kebiasaan merokok mempunyai nilai p paling besar yaitu 0,912 sehingga variabel kebiasaan merokok tidak lagi tercantum pada langkah kedua. Begitu juga pada langkah kedua ini, variabel dengan nilai $\mathrm{p}$ yang paling besar adalah variabel pola makan yaitu 0,176 , sehingga variabel pola makan tidak lagi tercantum pada langkah ketiga. Pada langkah ketiga ini didapatkan variabel yang berpegaruh terhadap kejadian hipertensi yaitu variabel aktifitas fisik dan kebiasaan istirahat yang merupakan hasil akhir dari analisis multivariat dengan menggunakan metode backward. Kekuatan hubungan dari yang terbesar ke yang terkecil adalah aktifitas fisik $(\mathrm{OR}=13,479)$ dan stres $(\mathrm{OR}=$ $0,196)$.

\section{PEMBAHASAN}

Berdasarkan hasil penelitian, mayoritas responden berusia $\geq 35$ tahun. Hal tersebut sesuai dengan penelitian Armeliawati, dkk (2007) bahwa 52,3\% orang yang berusia $\geq 35$ tahun yang menderita hipertensi. Hal ini sesuai dengan teori yang menyatakan bahwa hipertensi sering dijumpai pada orang berusia 35 tahun atau lebih (Kumar V, 2005). Dengan bertambahnya umur, risiko terjadinya hipertensi meningkat (Cardiology Chanel,2018). Hipertensi bisa terjadi pada segala usia, namun paling sering dijumpai pada usia 35 tahun atau lebih. Hal ini disebabkan oleh perubahan alami pada jantung, pembuluh darah dan 
hormon. Apabila perubahan tersebut disertai faktor-faktor lain maka bisa memicu terjadinya hipertensi (Bustan,2007). Hasil penelitian menunjukkan sebagian besar responden adalah laki-laki sebesar $48 \quad(66,6 \%)$ responden. Hal ini sesuai dengan teori dari Dalimartha, (2008) yang menyatakan bahwa hipertensi lebih mudah menyerang kaum laki-laki. Namun hal ini tidak sesuai dengan penelitian yang dilakukan oleh Raihan LN, dkk (2014) dengan prevalensi hipertensi pada wanita lebih besar dari pada lakilaki dengan presentase $44,9 \%$ pada lakilaki dan $55,1 \%$ pada wanita.

Mayoritas pendidikan terakhir responden yaitu SD. Hasil penelitian ini menunjukkan bahwa sebagian besar responden mempunyai pola pikir dan pengetahuan yang kurang dalam penyajian pola makan yang baik dan pola hidup yang sehat. Hasil penelitian ini sesuai dengan penelitian Mannan H (2012) bahwa orang dengan pendidikan tinggi mempunyai wawasan serta pegetahuan yang luas mengenai kesehatan dibandingkan dengan yang berpendidikan SD. Hal tersebut juga sesuai dengan teori Notoadmojo (2007) yang menyatakan bahwa pendidikan yang rendah akan menghasilkan pengetahuan yang rendah pula.
Hubungan variabel independen dengan kejadian hipertensi pada masyarakat di Pesisir Pantai Boom Kecamatan Pekalongan Utara Kota Pekalongan.

Berdasarkan hasil analisis multivariat menunjukkan bahwa dari 4 variabel yang dianalisis secara bersama-sama, terdapat 2 variabel yang terbukti sebagai faktor risiko kuat terjadinya hipertensi.

1. Hubungan aktifitas fisik dengan kejadian hipertensi.

Hasil penelitian yang telah dilakukan adalah terdapat hubungan yang bermakna secara statistik antara aktivitas fisik/olahraga dengan kejadian hipertensi. berdasarkan analisis diperoleh nilai $\mathrm{OR}=13.47$ dan artinya orang yang tidak teratur berolah raga memiliki risiko terkena hipertensi sebesar 13,47 kali dibandingkan dengan orang yang memiliki kebiasaan olah raga teratur. Maka dapat disimpulkan bahwa aktifitas fisik merupakan faktor risiko terjadinya hipertensi. Hal ini sesuai dengan hasil penelitian Mannan H (2012) bahwa terdapat hubungan yang signifikan antara aktifitas fisik/olahraga dengan kejadian hipertensi dengan nilai $\mathrm{OR}=2,67$. Hal ini juga sesuai dengan penelitian yang dilakukan oleh Raihan LN (2014) bahwa aktifitas fisik/olahraga merupakan faktor resiko hipertensi. 
Kurangnya aktifitas fisik meningkatkan risiko menderita hipertensi karena meningkatkan ririko kelebihan berat badan. Orang yang tidak aktif juga cenderung mempunyai frekuensi denyut jantung yang lebih tinggi sehingga otot jantungnya harus bekerja lebih keras pada setiap kontraksi. Makin keras dan sering otot jantung harus memompa, makin besar tekanan yang di bebankan pada arteri (Scholze J,2007). Masyarakat pesisir Kota Pekalongan sebagian besar berprofesi sebagai pedagang sekaligus sebagai buruh, mereka bekerja pada siang hari kemudian berdagang di malam hari, sehingga mereka tidak memiliki waktu untuk berolahraga dengan teratur.

2. Hubungan kebiasaan istirahat dengan kejadian hipertensi.

Hasil penelitian yang telah dilakukan adalah terdapat hubungan yang bermakna secara statistik antara kebiasaan istirahat dengan kejadian hipertensi. berdasarkan analisis diperoleh nilai $\mathrm{OR}=0.19$ dan artinya orang yang kebiasaan istirahat yang kurang berisiko terkena hipertensi sebesar 0,19 kali dibandingkan dengan orang yang memiliki kebiasaan tidur yang baik. Pola tidur yang buruk dapat mengakibatkan gangguan keseimbangan fi siologis dan psikologis dalam diri seseorang (Potter dan
Perry, 2006) Hal ini sesuai dengan pendapat Gangwisch, dkk (2006), bahwa seseorang yang memiliki kuantitas dan kualitas tidur kurang baik akan memicu stress psikologis dan fisik. Besarnya pengaruh pola tidur terhadap tekanan darah tergantung kuatnya sugesti atau stressor yang diarahkan pada organ yang mempunyai pengaruh besar terhadap tekanan darah seperti ginjal pada bagian adrenal korteks yang menghasilkan hormon kortisol dapat memicu kelenjar pituari bagian depan mensekresikan ACTH (Adreno Corticotropin Hormone). ACTH juga berperan membantu menghasilkan aldesteron yang menyebabkan peningkatan penyerapan ion natrium dan air pada ginjal. Peningkatan kadar garam dalam darah juga menekan ekskresi garam dalam ginjal dan meningkatkan hemodinamik selama 24 jam, akibatnya terjadi hiperterofi atrium dan ventrikel kiri jantung kemudian meningkatkan kerja jantung akibatnya terjadilah peningkatan tekanan darah. Tidur mempunyai peran penting dalam fungsi kekebalan tubuh, metabolisme, memori, pembelajaran, dan fungsi-fungsi penting lainnya. Tidur yang cukup dengan kualitas yang baik berpengaruh ketika seseorang beraktivitas. Orang yang kurang tidur bisa menjadi tidak fokus ketika melakukan aktivitas, merasa mudah lelah, dan mempunyai 
mood yang buruk. Banyak orang tidak menyadari akibat dari kurang tidur berkepanjangan yang seharusnya menjadi perhatian penting. Kurang tidur yang berlangsung pada waktu lama berhubungan dengan meningkatnya risiko mengalami masalah kesehatan kronis, salah satunya adalah kenaikan tekanan darah. Durasi tidur yang pendek selain dapat meningkatkan rata-rata tekanan darah dan denyut jantung, juga meningkatkan aktivitas sistem saraf simpatik dan merangsang stress, yang pada akhirnya bisa menyebabkan hipertensi. Perubahan emosi seperti tidak sabar, mudah marah, stress, cepat lelah, dan pesimis yang disebabkan karena durasi tidur yang kurang dapat meningkatkan risiko naiknya tekanan darah. Orang yang sudah memasuki usia paruh baya, apabila kurang tidur maka akan lebih rentan mengalami tekanan darah tinggi (Bansil, 2011).

Pola tidur yang baik meliputi durasi tidur yang sesuai dengan kebutuhan menurut umur, tidur nyenyak tidak terbangun karena suatu hal di selasela waktu tidur. Sedangkan pola tidur yang buruk meliputi durasi tidur yang kurang dari kebutuhan menurut umur, tidur terlalu larut malam dan bangun terlalu cepat, tidur tidak nyenyak sering terbangun karena suatu hal (Hidayat, 2008). Waktu paling optimal untuk mulai tidur di malam hari adalah jam 10 malam, selain untuk mengumpulkan energi dan tenaga juga sangat baik untuk kecantikan kulit, vitalitas tubuh, dan meningkatkan mood positif di pagi hari. Kebutuhan tidur seseorang berbeda-beda untuk umur 18-40 tahun kebutuhan tidur adalah 8-8 jam perhari, untuk umur 41-60 tahun kebutuhan tidur adalah 7 jam perhari, dan untuk umur 60 tahun keatas kebutuhan tidur adalah 6 jam perhari (Hidayat, 2008)

\section{Keterbatasan Penelitian}

Pengukuran terhadap variabel pola makan hanya terbatas pada frekuensi makan saja tanpa mengukur seberapa tinggi kadar nutrisi yang terkandung dalam makanan yang dikonsumsi.

\section{SIMPULAN DAN SARAN}

Berdasarkan penelitian yang dilakukan dapat diambil simpulan sebagai berikut :

1. Faktor-faktor yang terbukti merupakan faktor risiko terjadinya hipertensi adalah:

a. Tidak biasa melakukan aktifitas fisik atau olahraga mempunyai risiko menderita hipertensi sebesar 13,47 kali dibandingkan orang yang mempunyai kebiasaan melakukan aktifitas fisik atau olahraga.

b. Orang yang memiliki kebiasaan istirahat yang buruk mempunyai 
risiko menderita hipertensi sebesar 0,19 kali dibanding dengan orang yang memiliki kebiasaan istirahat yang baik.

2. Faktor-faktor yang tidak terbukti sebagai faktor risiko hipertensi adalah pola makan dan kebiasaan merokok.

\section{Berdasarkan penelitian yang telah}

\section{dilakukan maka peneliti menyarankan :}

1. Masyarakat perlu memeriksakan tekanan darah secara rutin agar tekanan darah bisa dikontrol setiap waktu.

2. Melakukan olahraga dengan benar secara teratur 3 sampai 4 kali seminggu minimal 30 menit dengan sifat kontinyu, ritmik, progresif, dan mempunyai kekuatan tertentu sesuai tujuan olah raga yang dilakukan. Sebelum melakukan olah raga, menghitung nadi terlebih dahulu dan sesaat setelah berolahraga nadi diharapkan mencapai zona sasaran $75 \%-85 \%$ dari nadi maksimal (220 - umur).

3. Mengatur pola tidur yang disesuaikan dengan umur masingmasing. 


\section{DAFTAR PUSTAKA}

Armilawati, Amalia H, Amirudin R. 2007. Hipertensi dan faktor risikonya dalam kajian epidemiologi. Bagian Epidemiologi FKM UNHAS. [serial online]. [dikutip tanggal 20 Oktober 2018]. Diakses dari : http://www.CerminDuniaKedokteran .com/index.php.

Bansil, P. 2011. Associations Between Sleep Disorders, Sleep Duration, Quality of Sleep, and Hypertension: Results From the National Health and Nutrition Examination Survey, 2005 to 2008. Division for Heart Disease and Stroke Prevention, Centers for Disease Control and Prevention: Atlanta.

Bustan MN. 2007. Epidemiologi penyakit tidak menular. Jakarta : Rineska Cipta. 29-38.

Cardiology Channel, Hipertension (High Blood Pressure): [Dikutip tanggal 19 Oktober 2018]. Diakses dari: http://www.cardiologychannel.com

Dalimarta. 2008. Care your self hipertensi. Jakarta. Penebar Plus

Dinkes Kota Pekalongan. 2018. Jumlah kasus penyakit terbanyak dan hipertensi di Pekalongan tahun 2018. Kota Pekalongan.

Gangwisch, JE., Heymsfi eld SB., Boden AB., Bujis RM., Kreier F., Pickering TG. 2006. Short Sleep Duration as a Risk Factor for Hypertension: Analyses of the First National health and Nutrition Examination Survey. American Heart Association: 7272 Greenville Avenue, Dallas.

Gray HH, Dawkins KD, Morgan JM, Simpson IA. 2005. Letcure notes: Kardiologi. Jakarta: Erlangga.57-69.

Hidayat, A., Musrifatul. 2008. Keterampilan Dasar Praktek Klinik untuk Kebidanan. Jakarta: Salemba Medika

Kumar V, Abbas AK, Nelson F. Hypertensive vascular disease.
Dalam : Robbin and Cotran. 2005. Pathologic Basis of Disease, 7th edition. Philadelphia : Elsevier Saunders, 528-29.

Mannan H. 2012. Faktor risiko kejadian hipertensi di wilayah kerja puskesmas Bangkala Kabupaten Jeneponto [skripsi]. Makasar : Universitas Hasanudin Makasar.

Musthofa K. 2013. Hubungan pengetahuan dengan perilaku penderita hipertensi dalam pencegahan stroke di Puskesmas Ponorogo Utara Kabupaten Ponorogo [skripsi]. Ponorogo: Universitas Muhammadiyah Ponorogo.

Notoadmodjo S. 2005. Ilmu Kesehatan Masyarakat Edisi I. Jakarta: Medika Cipta. 127-32

Notoadmodjo S.2002. Metodologi penelitian kesehatan. Jakarta : Rineka Cipta: 88-90.

Potter dan Perry. 2006. Fundamental Keperawatan. Jakarta: EGC.

Raihan LN, Erwin, Dewi AP. 2014. Faktor-faktor yang berhubungan dengan kejadian hipertensi primer pada masyarakat di wilayah kerja Puskesmas Rumbai Pesisir. [skripsi]. Pekanbaru; Universitas Riau.

Riset Kesehatan Dasar (Riskesdas). 2018. Badan penelitian dan pengembangan kesehatankementrian kesehatan RI.

Robbins. 2010. Buku ajar patologi, Edisi 7. Volume 2. Jakarta : Buku kedokteran EGC ; 379.

Rubenstein D, Wayne D, Bradley J. 2007. Letcure notes: Kedokteran Klinis. Jakarta: Erlangga; 317-21.

Scholze J, Grimm E, Herrmann D, Unger T, Kintscher U. 2007. Treatment of obesity related hypertension ; the hypertension obesity sibutramine (HOS) study. Circulation. 155: 9198.

Sherwood L. 2014. Fisiologi manusia dari sel ke sistem. Edisi 8. Jakarta : Buku kedokteran EGC ; 408. 
Sugiharto A. 2007. Faktor-faktor risiko hipertensi grade II pada masyarakat (studi kasus di Kabupaten Karanganyar) [tesis]. Semarang: Universitas Diponegoro.

Tim Redaksi Vitahealth (Sustrani L, Alam S, Hadibroto I). 2006. Hipertensi. Jakarta: PT Gramedia Pustaka Utama. 2006. 12,26.
World Health Organization (WHO). World health day 2013: calls for intensified efforts to prevent and control hypertension. 2013. [cited 2014 Dec 19] Available from: http://www.who.int/workforcealianc e/media/news/2013/who2013story/e n/ 